\title{
Menikah adalah Ibadah: \\ Peran Agama dalam Mengkonstruksi Pengalaman Melajang di Indonesia
}

\author{
Karel K. Himawan \\ Fakultas Psikologi, Universitas Pelita Harapan, Indonesia \\ Faculty of Medicine, the University of Queensland, Australia \\ k.himawan@uq.net.au
}

\begin{abstract}
Religion plays a major role in the lives of most Indonesians. While most religions favour marriage, little is known regarding how religion shapes the singleness experience, especially from the Indonesian perspective. The study aims to explore whether and how religion constructs the meaning of singleness and contributes to the quality of life of Indonesian unmarried individuals. Multistage mixed-methods study was employed to answer the research questions through two stages. Stage one was an online survey to 635 participants (Mage $=31.49 ; \mathrm{SD}=5.49)$ across three groups (single, single in a relationship, and married). Stage two utilised interviews to 40 unmarried participants (Mage $=33.14$; $\mathrm{SD}=4.04$ ). The survey results suggest that as a group, single individuals indicated lower levels of quality of life compared to married people. Among single participants, multivariate analysis suggests that religiosity significantly increases life satisfaction, but does not reduce loneliness. Three themes emerged regarding the role of religion in constructing the meaning of singleness: singleness as a God-willed temporary period, a period to embrace life outside marriage, and a period where conservative socio-religious norms are negotiated with contemporary values. The study highlights the complex and pivotal role of religion in the Indonesian singleness experience
\end{abstract}

KEYWORDS: Life Satisfaction | Loneliness | Never-married | Religion | Religiosity | Singleness

\section{PENDAHULUAN}

Anggapan yang menjadikan menikah sebagai norma bagi individu di rentang usia tertentu sepertinya mulai ditinggalkan, terlihat dari semakin banyaknya kaum muda yang memilih untuk tetap melajang dan menunda pernikahannya. Gaya hidup lajang mulai menjadi preferensi di negara Barat (DePaulo 2013), termasuk di berbagai negara Asia (Himawan, Bambling and Edirippulige 2018a; Jones, Yanxia and Zhi 2012). Keputusan untuk menikah sebenarnya memang merupakan pilihan sukarela individu yang melekat sebagai bagian dari hak asasinya sebagai manusia (United Nations 1948). Ini berarti, menikah dan melajang merupakan pilihan pribadi yang perlu dihormati. Namun, keputusan untuk tetap melajang di Indonesia mengandung konsekuensi mendapat tekanan sosial dan budaya (Himawan 2019a). Nilainilai budaya konservatif masih dianut sebagian besar masyarakat Indonesia, di mana individu yang tetap melajang di usia kebanyakan orang sudah menikah mendapat pandangan negatif karena pernikahan dianggap merepresentasikan "prestasi sosial" seseorang (Himawan 2019a).

Interaksi nilai sosial, budaya, dan agama di Indonesia dalam memaknai pernikahan menyajikan konteks yang menarik untuk mengeksplorasi pengalaman melajang. Ini karena masyarakat Indonesia menganggap afiliasi agama, status pernikahan $\left(\mathrm{Hi}^{-}\right.$ mawan 2020b), serta konformitas terhadap praktik-praktik budaya khususnya terkait pernikahan (Beta and Febrianto 2020; Colquhoun and Nilan 
2020) sebagai faktor penting yang mendefinisikan identitas sosialnya. Agama bukan hanya menjadi atribut identitas bagi penganutnya, tetapi memiliki manfaat psikologis yang penting dalam menunjang kesehatan mental (Pargament et al. 1992). Berbagai studi internasional menunjukkan bagaimana penghayatan terhadap nilai-nilai spiritual berkontribusi signifikan dalam meningkatkan kesejahteraan psikologis seseorang (Cappellen et al. 2016; McConnell et al. 2006), termasuk bagi orang-orang yang tidak menikah (Granqvist and Hagekull 2009).

Studi-studi terhadap individu yang tidak menikah di Indonesia belum banyak dilakukan. Studi yang ada cenderung berfokus pada pengalaman lajang dari sudut pandang perempuan dengan sampel kecil melalui pendekatan kualitatif (Situmorang 2007; Tan 2010). Padahal, implikasi sosial akibat status lajang juga turut dirasakan oleh lelaki (Himawan 2019a). Lebih lanjut, belum ada studi empiris yang mengaitkan bagaimana afiliasi agama dan tingkat religiusitas seseorang mempengaruhi pengalamannya sebagai lajang di Indonesia. Oleh karenanya, studi ini berusaha mengisi kekosongan tersebut dengan secara khusus mengeksplorasi bagaimana agama berkontribusi dalam mengkonstruksi makna serta memengaruhi kualitas hidup lajang di Indonesia melalui desain multistage mixed-methods.

\section{PREFERENSI DAN PERSEPSI TERHADAP LAJANG DI DUNIA}

Arus kajian lintas budaya tentang pernikahan dan keluarga menunjukkan pola terbaru, khususnya dalam dua abad terakhir, yang dikarakteristikkan dengan semakin tingginya minat generasi muda untuk tetap melajang (Daugherty and Copen 2016; Jones 2010). Fenomena ini bersifat global, data internasional secara konsisten menunjukkan semakin banyaknya individu yang menunda usia pernikahan dan menjalin hubungan romantis di luar institusi pernikahan (kohabitasi) (Australian Bureau of Statistics 2016, Corselli-Nordblad and Gereoffy 2015; US Census Bureau 2015). Peningkatan jumlah lajang yang dikarakteristikkan dengan penundaan usia pernikahan juga dapat diamati di sebagian besar negara di Asia (Jones 2010), dimana kohesivitas budaya khususnya mengenai preferensi terhadap pernikahan cenderung lebih kuat dibandingkan pada budaya-budaya Barat (Yeung and Hu 2016).

Peningkatan proporsi individu yang tidak menikah berkembang paralel dengan semakin positifnya persepsi terhadap lajang, yang memunculkan pandangan mengenai lajang sebagai pilihan hidup (voluntary single) (DePaulo 2013), dan bukan sebagai kondisi terpaksa ketika seseorang tidak dapat menemukan pendamping hidupnya (involuntary single). Studi terdahulu yang mengaitkan manfaat pernikahan terhadap kesehatan mental seseorang (Hirschl, Altobelli and Rank 2003, Myers 2000) mulai diragukan relevansinya. Chapman dan Guven (2016), misalnya, menunjukkan bahwa relasi kausal mengenai pernikahan dan kebahagiaan tidak dapat dibuktikan. Sebaliknya, hasil studinya menunjukkan bahwa orang-orang yang lebih berbahagia cenderung berakhir tetap melajang atau memiliki pernikahan yang berbahagia. Dengan kata lain, tingkat kebahagiaan seseorang bukanlah prediktor terhadap kecenderungannya untuk menikah, begitu pula pernikahan tidak dapat memprediksi kebahagiaan. Kesimpulan ini juga diperkuat dengan studi berdasarkan data longitudinal selama 15 tahun yang menunjukkan bahwa kepuasan hidup seseorang berfluktuasi sebagai reaksi atas berbagai peristiwa yang terjadi di dalam hidupnya (termasuk pernikahan), dan cenderung berangsur-angsur kembali ke titik semula setelah beberapa waktu pasca peristiwa tersebut (Lucas et al. 2003). Namun, studi-studi tersebut mengacu pada konteks budaya Barat, dimana meski stigma terhadap lajang masih ada, terdapat ruang sosial dan apresiasi yang cukup bagi individu untuk menjadikan lajang sebagai pilihan hidup (Himawan, Bambling and Edirippulige 2018a). Di beberapa budaya Asia, termasuk di Indonesia, persepsi budaya tentang pernikahan dapat memegang peranan penting dalam menentukan kebahagiaan individu.

\section{LAJANG DALAM KONTEKS INDONESIA}

Tren kependudukan di Indonesia menunjukkan pola yang selaras dengan data internasional mengenai peningkatan jumlah penduduk lajang di 
usia menikah (Badan Pusat Statistik 2010, Jones 2010). Ada dua indikasi penting yang menunjukkan pola tersebut. Pertama, terjadi peningkatan usia individu memasuki pernikahan pertama dalam kurun waktu empat dekade terakhir, di mana pada tahun 2010 seseorang menikah rata-rata tiga tahun lebih tua dibanding individu seusianya pada tahun 1970 (Badan Pusat Statistik 2010; Jones 2010). Kedua, jumlah penduduk perempuan berusia 35-39 tahun juga mengalami peningkatan sebesar hampir tiga kali lipat menjadi 3.8\% dalam empat dekade terakhir (Badan Pusat Statistik 2010; Jones 2010). Hasil sensus terakhir tahun 2010 menunjukkan bahwa jumlah individu berusia 30-39 tahun yang belum menikah mencapai lebih dari 7\% (Badan Pusat Statistik 2010) - ini merupakan proporsi terbesar sepanjang sejarah.

Meskipun jumlah lajang meningkat di Indonesia, beberapa studi awal mengindikasikan bahwa sebagian besar lajang di Indonesia tidak secara sukarela ingin tetap melajang (involuntarily single) ( $\mathrm{Hi}-$ mawan 2019a, Himawan 2019b, Situmorang 2007, Vignato 2012). Berbagai faktor berperan dalam menjelaskan situasi dimana seseorang ingin, namun tidak dapat, menikah, di antaranya pergeseran ekspektasi mengenai pernikahan dan peran gender di dalam rumah tangga dan transisi nilai-nilai budaya akibat modernisasi (Himawan, Bambling and Edirippulige 2019).

Salah satu dampak nyata dari modernisasi adalah transformasi nilai-nilai budaya yang mengedepankan kesamaan gender. Prinsip kesetaraan gender dalam pendidikan dan industri terlihat dari meningkatnya partisipasi perempuan dalam menempuh pendidikan tinggi (Setyonaluri, Maghfirah, and Aryaputra, 2020), yang akhirnya membuka peluang bagi mereka untuk membangun karier dan berperan di luar peran tradisionalnya sebagai ibu rumah tangga (Utomo 2014). Di sisi lain, sebagian besar masyarakat Indonesia masih memandang penting bentuk pernikahan hipergami, di mana pernikahan dianggap ideal ketika status ekonomi dan sosial suami lebih tinggi daripada status istri (Himawan 2020a). Dengan semakin besarnya proporsi perempuan yang berkecimpung di bidang pendidikan dan oleh perubahan sosial yang cepat dan masif. Kecendkarier, peluang untuk menemukan pasangan dengan status sosioekonomi yang lebih rendah darinya menjadi semakin kecil, yang akhirnya berkontribusi meningkatkan proporsi lajang.

\section{PERAN AGAMA DALAM MENGKON- STRUKSI PENGALAMAN MELAJANG}

Sikap positif terhadap pernikahan bagi masyarakat Indonesia, di samping merefleksikan profil budaya kolektif di mana apresiasi terhadap individu lebih dilihat dalam konteks relasi dan kekerabatannya (Hofstede Insights 2018), juga menggambarkan bagaimana nilai-nilai agama terabsorbsi dalam membentuk sistem nilai kemasyarakatan. Studi menunjukkan bahwa agama dan gender memberi warna tersendiri bagi pengalaman melajang di Indonesia, di mana perempuan yang belum menikah cenderung mengalami masa lajang yang kurang menyenangkan (Himawan 2020a). Dalam studi ini, pengalaman melajang difokuskan pada bagaimana lajang memaknai status lajangnya serta mengupayakan kualitas hidupnya.

Sebagian besar agama umumnya mendukung pernikahan (Himawan, Bambling and Edirippulige 2018b). Argumen ini dimaknai lebih lanjut oleh sebagian pemeluk agama bahwa ketidakmampuan untuk menikah berimplikasi pada pengingkaran terhadap perintah agama, sehingga menikah dipercaya sebagai bentuk perilaku taat agama. Beberapa individu yang beragama Islam, misalnya, memaknai menikah sebagai wujud ibadah (Asyari and Abid 2016, Ibrahim and Hassan 2009). Hull (2016) berpendapat bahwa terpeliharanya sikap positif terhadap pernikahan pada masyarakat Indonesia juga disebabkan karena pernikahan dianggap sebagai satu-satunya cara seorang dewasa untuk terbebas dari dosa akibat godaan seksual. Maka, seseorang yang tidak menikah kerap dipersepsikan secara sengaja menempatkan dirinya dalam kerawanan berbuat dosa. Menjadikan pernikahan sebagai perintah agama berpotensi memberi tekanan spiritual, psikologis, dan sosial pada lajang (Himawan 2019a)

Di sisi lain, penghayatan spiritual dan keterli- 
batan sosial pada acara. keagamaan dapat membantu lajang dalam menghadapi tekanan sosial akibat status lajangnya. Relasi intim dengan Tuhan (atau pada figur spiritual lain yang dipercaya menurut agamanya) dapat memenuhi kebutuhan berelasi individu (Kirkpatrick 1992), yang bersifat mendasar dan berperan penting bagi kesejahteraan psikologis seseorang (Baumeister and Leary 1995). Secara normatif, kebutuhan ini dipenuhi melalui relasi pernikahan pada individu dewasa. Relasi spiritual yang dibangun individu lajang juga dapat menawarkan pemenuhan kebutuhan emosional alternatif dari relasi pernikahan yang tidak atau belum dimilikinya ( $\mathrm{Hi}^{-}$ mawan, Bambling and Edirippulige 2018b, Himawan 2020b). Lebih lanjut, komunitas keagamaan juga cenderung lebih mengayomi (Dingemans and Ingen 2015), sehingga dapat memfasilitasi kebutuhan bersosialisasi lajang tanpa merasa dihakimi karena status lajangnya.

\section{KONSEPTUALISASI STUDI}

Berdasarkan konsep-konsep yang telah dipaparkan di atas, studi ini berupaya untuk mendemonstrasikan peran agama dalam mengkonstruksikan pengalaman lajang di Indonesia. Secara khusus, ada dua pertanyaan pada studi ini:

1. Apakah agama berperan dalam memengaruhi kualitas hidup lajang di Indonesia?

2. Bagaimana peran agama dalam mengkonstruksi makna lajang di Indonesia?

Desain multistage mixed-methods dengan tipe sequential exploratory strategy (Creswell 2003) dipilih untuk mengakomodasi pertanyaan penelitian. Studi ini terdiri dari dua fase. Fase pertama ialah studi survei yang bertujuan untuk mengidentifikasi pola hubungan keterlibatan agama (religiusitas) dalam memengaruhi kualitas hidup lajang, yang dilihat melalui dua indikator: tingkat kepuasan hidup dan kesepian. Hipotesis yang dibangun ialah tingginya tingkat religiusitas lajang akan memprediksi tingginya skor kepuasan hidup dan rendahnya skor kesepian.

Pada fase kedua, wawancara dilakukan terhadap lajang untuk secara fokus mengeksplorasi ba- gaimana agama berperan dalam mengkonstruksi makna lajangnya. Wawancara dilakukan dengan format semi struktural, menggunakan daftar pertanyaan yang telah dirumuskan sesuai dengan pertanyaan penelitian. Namun fleksibilitas untuk mengembangkan pertanyaan dimungkinkan saat wawancara mengingat perspektif partisipan lebih diutamakan dalam mengkonstruksi fenomena.

Studi ini merupakan bagian dari studi 'Why I Do?' yang bertujuan untuk mengeksplorasi pengalaman melajang di Indonesia. Aspek etik studi ini telah dievaluasi dan mendapat persetujuan dari The Institutional Human Research Ethics Committee of the University of Queensland (no: 2017000826).

\section{FASE 1: METODE SURVEI}

\section{Partisipan}

Kriteria pemilihan partisipan ialah: 1). lelaki atau perempuan berusia 26-50 tahun, 2). belum pernah menikah, 3). dapat berkomunikasi dalam Bahasa Indonesia, dan 4). tidak berorientasi homoseksual. Untuk analisa data tambahan dalam membandingkan profil kualitas hidup berdasarkan status relasinya, partisipan berstatus menikah turut diundang berpartisipasi. Dengan demikian, total partisipan ialah 635 partisipan $($ Musia $=31.49$; $S D=$ 5.49), yang terbagi dalam tiga kelompok sampel: lajang tidak berpacaran $(n=215)$, lajang berpacaran $(n$ $=130)$, dan menikah $(n=350)$.

Mayoritas partisipan lajang adalah perempuan $(71.2 \%)$. Hampir seluruh partisipan mengidentifikasikan dirinya sebagai involuntary single (94\%). Sebesar 37.7\% mengaku sedang berpacaran saat berpartisipasi. Mengenai afiliasi agama, mayoritas partisipan beragama Islam (51.4\%), diikuti oleh agama Kristen Protestan (25.4\%), Katolik (13.7\%), Budha (4.3\%), dan Hindu (1.1\%), sedangkan 4\% lainnya ialah ateis atau tidak menjawab. Partisipan beretnis Jawa mendominasi kelompok sampel (33.6\%), diikuti oleh etnis Cina (26.7\%), Batak (8.7\%), Padang $(5.8 \%)$, Sunda $(5.2 \%)$, dan Bali $(1.2 \%)$, sementara $18.8 \%$ sisanya bergolongan etnis minor lainnya.

Instrumen 
The Four Basic Dimensions of Religiosity Scale (4BDRS). Alat ukur berjumlah 12 butir ini dikembangkan oleh Saroglou (2009) untuk mengukur tingkat religiusitas individu dalam empat dimensi: Believing, Bonding, Belonging, dan Behaving: Partisipan merespons dalam 7 pilihan jawaban $(1=$ Sangat Tidak Setuju; $7=$ Sangat Setuju). Skala ini diterjemahkan ke Bahasa Indonesia dan menghasilkan skor Cronbach's Alpha .933.

Satisfaction with Life Scale (SWLS). Skala ini terdiri dari lima pernyataan, dikembangkan oleh Diener et al. (1985), untuk mengukur kepuasan hidup. Partisipan merespons dalam 7 pilihan jawaban (1 = Sangat Tidak Setuju; 7 = Sangat Setuju). Versi Bahasa Indonesia dari skala ini menghasilkan skor Cronbach's alpha sebesar .851.

UCLA Loneliness Scale (ULS-8). Skala ini dikembangkan oleh Hays and Di Matteo (1987) untuk mengukur tingkat kesepian seseorang melalui delapan butir pernyataan. Partisipan meresponsnya dalam empat pilihan jawaban $(1=$ tidak pernah; $4=$ selalu). Nilai Cronbach's alpha pada versi Bahasa Indonesia skala ini ialah .702.

\section{Prosedur}

Survei dilakukan secara daring pada bulan Maret - Juli 2018. Tautan survei disebar melalui beberapa platform media sosial, seperti: Whatsapp, Facebook, Instagram, dan mailing list. Sebelumdapat mengakses survei, partisipan terlebih dahulu disajikan informasi mengenai studi, termasuk risiko dan kerahasiaan data. Partisipan diminta menyatakan persetujuannya terhadap ketentuan studi dengan menekan tombol "setuju" sebelum dapat mengakses laman survei. Dalam survei, partisipan diminta untuk mengisi informasi demografis serta memberikan respons terhadap instrumen studi. Partisipan yang belum menikah diminta mengidentifikasi apakah status lajangnya merupakan pilihan sukarela atau tidak.

Sebagai apresiasi atas waktu partisipan, di akhir halaman survei partisipan diberi kesempatan untuk berpartisipasi dalam undian berhadiah total Rp 1.000.000,- untuk lima orang pemenang yang dipilih secara acak. Informasi personal yang dimasukkan partisipan untuk program undian tidak terhubung dengan data penelitian, sehingga responnya tidak dapat teridentifikasi.

\section{Teknik Analisis}

Analisis utama menggunakan teknik regresi hierarki, dimana skor religiusitas dijadikan sebagai variabel prediktor (IV) terhadap kepuasan hidup (DV1) dan kesepian (DV2) dengan mengontrol jenis kelamin, agama, pendidikan, pekerjaan, penghasilan, etnis, dan agama. Teknik statistik lain, seperti: uji T-Test, korelasi Pearson, dan ANOVA digunakan untuk analisa tambahan.

HASIL

Korelasi Antar Variabel Studi

Tabel 1.

Korelasi antar Variabel Studi

\begin{tabular}{lllllll}
\hline & Usia & Pendidikan & Penghasilan & 4BDRS & SWLS & ULS-8 \\
Usia & & & & & \\
Pendidikan & .028 & & & & \\
Penghasilan & $.254^{* *}$ & $.114^{*}$ & & & \\
4BDRS & $.094^{*}$ & -.076 & $-.107^{*}$ & & \\
SWLS & $.096^{*}$ & $.121^{*}$ & $.161^{* *}$ & $.221^{* *}$ & \\
ULS-8 & $-.084^{*}$ & $-.094^{*}$ & -.048 & $-.137^{* *}$ & $-.403^{* *}$ & \\
\hline
\end{tabular}

Catatan: ${ }^{*}=$ signifikan pada taraf $.05 ;{ }^{*}=$ significant pada taraf $.001 ; 4 \mathrm{BDRS}=$ skor religiusitas; SWLS = skor kepuasan hidup; ULS-8 = skor kesepian 
Tabel 1 merangkum korelasi antara berbagai variabel penelitian. Korelasi negatif antara skor kepuasan hidup dengan skor kesepian menunjukkan bukti validitas konstruk bahwa kedua variabel tersebut memiliki konstruk yang berlawanan. Selanjutnya, korelasi yang signifikan antara tingkat religiusitas dengan tingkat kepuasan hidup dan kesepian, menunjukkan bahwa nilai-nilai religiusitas secara umum masih memegang peranan yang bermakna dalam menentukan kualitas hidup seseorang.
Kontribusi Religiusitas terhadap Kepuasan Hidup Lajang

Hasil uji regresi hierarki menunjukkan bahwa tingkat religiusitas berkontribusi signifikan terhadap kepuasan hidup partisipan (lihat Tabel 2 model 2). Kemudian, analisis dilakukan secara terpisah pada partisipan yang sedang dan tidak berpacaran. Hasil menunjukkan bahwa kontribusi religiusitas terhadap kepuasan hidup terbukti hanya pada partisipan yang sedang tidak berpacaran (lihat Tabel 2 Model 4).

Tabel 2.

Uji Regresi Hierarki Religiusitas terhadap Kepuasan Hidup Lajang yang Berpacaran dan Tidak

\begin{tabular}{|c|c|c|c|c|c|c|c|c|c|c|c|c|}
\hline & \multicolumn{4}{|c|}{$\begin{array}{c}\text { Total } \\
(\mathrm{N}=350) \\
\end{array}$} & \multicolumn{4}{|c|}{$\begin{array}{l}\text { Tidak Berpacaran } \\
\qquad(\mathrm{N}=215)\end{array}$} & \multicolumn{4}{|c|}{$\begin{array}{l}\text { Berpacaran } \\
(\mathrm{N}=130) \\
\end{array}$} \\
\hline & \multicolumn{2}{|c|}{ Model 1} & \multicolumn{2}{|c|}{ Model 2} & \multicolumn{2}{|c|}{ Model 3} & \multicolumn{2}{|c|}{ Model 4} & \multicolumn{2}{|c|}{ Model 5} & \multicolumn{2}{|c|}{ Model 6} \\
\hline & $R^{2}$ & $t$ & $R^{2}$ & $t$ & $R^{2}$ & $t$ & $R^{2}$ & $t$ & $R^{2}$ & $t$ & $R^{2}$ & $t$ \\
\hline \multicolumn{13}{|l|}{ Blok 1} \\
\hline Jenis kelamin & -.005 & -.091 & -.023 & -.439 & .001 & .001 & -.031 & -.468 & -.010 & -.109 & -.017 & -.194 \\
\hline Usia & .088 & 1.587 & .056 & 1.034 & .108 & 1.507 & .067 & .993 & .082 & .898 & .075 & .820 \\
\hline Pendidikan & .081 & 1.464 & .093 & 1.756 & .050 & .711 & .072 & 1.098 & .116 & 1.275 & .117 & 1.288 \\
\hline Pekerjaan & -.035 & -.647 & -.028 & -.534 & -.046 & -.661 & -.028 & -.431 & -.041 & -.449 & -.040 & -.436 \\
\hline Penghasilan & .085 & 1.498 & .125 & $2.275^{*}$ & .103 & 1.420 & .116 & 1.712 & .053 & .562 & .093 & .940 \\
\hline Etnis & -.008 & -.131 & -.034 & -.602 & -.054 & -.708 & -.074 & -1.043 & .046 & .483 & .024 & .244 \\
\hline Agama & .046 & .790 & .139 & $2.382^{*}$ & .034 & .454 & .140 & $1.963^{*}$ & .060 & .631 & .110 & 1.075 \\
\hline \multicolumn{13}{|l|}{ Blok 2} \\
\hline Religiusitas & & & 0.289 & $5.190^{* *}$ & & & 0.382 & $5.698^{* *}$ & & & 1.338 & .183 \\
\hline Adjusted $\mathrm{R}^{2}$ & \multicolumn{2}{|c|}{.011} & \multicolumn{2}{|c|}{.082} & \multicolumn{2}{|c|}{.001} & \multicolumn{2}{|c|}{.133} & \multicolumn{2}{|c|}{.015} & \multicolumn{2}{|c|}{.009} \\
\hline $\mathrm{F}$ & \multicolumn{2}{|c|}{1.542} & \multicolumn{2}{|c|}{$4.820^{* *}$} & \multicolumn{2}{|c|}{1.022} & \multicolumn{2}{|c|}{$5.088^{* *}$} & \multicolumn{2}{|c|}{.721} & \multicolumn{2}{|c|}{.859} \\
\hline Effect size & & & \multicolumn{2}{|c|}{.089} & \multicolumn{6}{|c|}{.154} & \multicolumn{2}{|c|}{-} \\
\hline
\end{tabular}

Catatan: ${ }^{*}=$ signifikan pada taraf $.05 ;{ }^{* *}=$ signifikan pada taraf .001 
Tabel 3 .

Uji Regresi Hierarki Religiusitas terhadap Kesepian Lajang yang Berpacaran dan Tidak

\begin{tabular}{|c|c|c|c|c|c|c|c|c|c|c|c|c|}
\hline & \multicolumn{4}{|c|}{$\begin{array}{c}\text { Total } \\
(\mathrm{N}=350)\end{array}$} & \multicolumn{4}{|c|}{$\begin{array}{l}\text { Tidak Berpacaran } \\
\qquad(\mathrm{N}=215)\end{array}$} & \multicolumn{4}{|c|}{$\begin{array}{c}\text { Berpacaran } \\
(\mathrm{N}=130)\end{array}$} \\
\hline & \multicolumn{2}{|c|}{ Model 1} & \multicolumn{2}{|c|}{ Model 2} & \multicolumn{2}{|c|}{ Model 3} & \multicolumn{2}{|c|}{ Model 4} & \multicolumn{2}{|c|}{ Model 5} & \multicolumn{2}{|c|}{ Model 6} \\
\hline & $R^{2}$ & $t$ & $R^{2}$ & $t$ & $R^{2}$ & $t$ & $R^{2}$ & $t$ & $R^{2}$ & $t$ & $R^{2}$ & $\mathrm{t}$ \\
\hline \multicolumn{13}{|l|}{ Blok 1} \\
\hline Jenis kelamin & -.131 & $-2.413^{*}$ & -.126 & $-2.321^{*}$ & -.085 & -1.215 & -.077 & -1.104 & -.198 & $-2.248^{*}$ & -.193 & $-2.180^{* *}$ \\
\hline Usia & -.052 & -.936 & -.043 & -.772 & -.110 & -1.533 & -.100 & -1.384 & -.018 & -.196 & -.012 & -.138 \\
\hline Pendidikan & -.064 & -1.163 & -.067 & -1.226 & -.051 & -.720 & -.056 & -.798 & -.062 & -.698 & -.063 & -.705 \\
\hline Pekerjaan & .085 & 1.565 & .083 & 1.530 & .070 & 1.005 & .065 & .942 & .147 & 1.639 & .146 & 1.628 \\
\hline Penghasilan & .033 & .579 & .022 & .380 & .033 & .453 & .030 & .410 & .048 & .513 & .019 & .193 \\
\hline Etnis & .046 & .790 & .053 & .911 & .068 & .895 & .073 & .961 & .046 & .495 & .063 & .659 \\
\hline Agama & -.055 & -.959 & -.081 & -1.335 & -.004 & -.048 & -.030 & -.392 & -.117 & -1.247 & -.153 & -1.519 \\
\hline \multicolumn{13}{|l|}{ Blok 2} \\
\hline Religiusitas & & & -.079 & -1.365 & & & -.095 & -1.320 & & & -.098 & -.983 \\
\hline Adjusted R2 & \multicolumn{2}{|c|}{.035} & \multicolumn{2}{|c|}{.040} & \multicolumn{2}{|c|}{.002} & \multicolumn{2}{|c|}{.002} & \multicolumn{2}{|c|}{.017} & \multicolumn{2}{|r|}{.017} \\
\hline $\mathrm{F}$ & \multicolumn{2}{|c|}{1.734} & \multicolumn{2}{|c|}{1.754} & \multicolumn{2}{|c|}{.942} & \multicolumn{2}{|c|}{1.045} & \multicolumn{2}{|c|}{1.324} & \multicolumn{2}{|c|}{1.279} \\
\hline
\end{tabular}

Effect size

Catatan: ${ }^{*}=$ signifikan pada taraf $.05 ;{ }^{* *}=$ significant pada taraf .001

Kontribusi Religiusitas terhadap Kesepian Lajang

Uji regresi hierarki menunjukkan bahwa religiusitas tidak memberi kontribusi signifikan terhadap tingkat kesepian lajang (lihat Tabel 2 model 2), baik pada partisipan yang berpacaran (lihat Tabel 2 model 6) maupun tidak (lihat Tabel 2 model 4).

\section{Komparasi Profil Kualitas Hidup Berdasarkan Status Pernikahan}

Analisis ANOVA dengan post hoc Bonferroni menunjukkan bahwa partisipan berstatus menikah memiliki tingkat kepuasan hidup yang lebih besar secara signifikan $(F=15.290 ; p=.000)$ dibanding partisipan yang berpacaran $(M D=1.892 ; p=.003)$ dan tidak $(M D=2.642 ; p=.000)$.

Mengenai tingkat kesepian, perbedaan signifikan antar-kelompok juga terbukti $(F=9.814 ; p$ $=.000)$, dimana tingkat kesepian paling tinggi dimiliki oleh kelompok partisipan yang tidak berpacaran, disusul oleh kelompok partisipan berpacaran, dan 
mereka yang menikah. Tidak ditemukan perbedaan skor kesepian yang signifikan antara partisipan yang berpacaran dan yang menikah $(M D=.450 ; p=$ $.863)$.

Kedua temuan di atas mengindikasikan bahwa keberadaan pasangan dapat secara signifikan mengurangi tingkat kesepian seseorang, namun hanya status pernikahan yang berkontribusi signifikan dalam meningkatkan kepuasan hidup.

\section{DISKUSI}

Studi fase ini berfokus untuk mengeksplorasi apakah religiusitas mempengaruhi kualitas hidup lajang di Indonesia. Hasil analisa menunjukkan tiga temuan penting mengenai pengalaman lajang di Indonesia: 1). Religiusitas terbukti berkontribusi dalam meningkatkan kepuasan hidup lajang di Indonesia, 2). Tingkat religiusitas lajang tidak berkontribusi dalam menurunkan rasa kesepiannya, dan 3). Jika dibandingkan dengan pasangan menikah, lajang di Indonesia cenderung melaporkan kualitas hidup yang lebih rendah.

Studi ini menunjukkan bahwa keterlibatan dalam berbagai aktivitas keagamaan dapat meningkatkan kepuasan hidup pada lajang, khususnya bagi mereka yang tidak sedang menjalin hubungan romantis. Hasil ini sesuai dengan studi di Swedia (Granqvist and Hagekull 2009), dimana individu yang tidak sedang berpacaran ditemukan lebih aktif dalam berbagai kegiatan keagamaan serta menganggap relasi spiritualnya sebagai relasi yang bermakna. Peran religiusitas dalam meningkatkan kepuasan hidup lajang dapat dilihat melalui aspek kognitif-spiritual dan sosial yang ditawarkan agama (Himawan, Bambling and Edirippulige 2018b). Secara kognitif-spiritual, religiusitas membantu individu untuk memaknai masa-masa dalam hidupnya secara positif (Pargament and Park 1995), termasuk masa lajang yang sebetulnya tidak diinginkan partisipan. Aspek sosial religiusitas memfasilitasi lajang untuk memenuhi kebutuhan relasionalnya di dalam komunitas agama yang cenderung lebih terbuka, menerima, dan mengayomi (Dingemans and Ingen 2015).
Religiusitas tidak terbukti mengurangi tingkat kesepian lajang. Temuan ini mungkin disebabkan karena tingkat kesepian dalam studi ini diukur sebagai variabel yang umum sehingga tidak dapat secara spesifik mengidentifikasi aspek kesepian yang dialami partisipan. Secara konseptual, kesepian merupakan variabel multifaset yang di dalamnya juga tercakup kesepian karena ketiadaan relasi romantis (romantic loneliness) (Adamczyk 2017). Dalam hal ini, mungkin kesepian dalam konteks romantis hanya dapat dipenuhi melalui relasi romantis.

Hasil uji komparatif antara partisipan yang sudah dan belum menikah menunjukkan bahwa partisipan menikah memiliki kepuasan hidup yang lebih tinggi serta lebih tidak merasa kesepian. Lebih lanjut, keberadaan pasangan, walau bukan dalam relasi pernikahan, dapat mengurangi rasa kesepian seseorang, tetapi tidak cukup untuk meningkatkan kepuasan hidupnya. Berbeda dengan temuan di negara-negara Barat (Depaulo 2009; Sarkisian and Gerstel 2016), bahkan di beberapa negara Asia seperti Singapura (Jones, Yanxia and Zhi 2012), temuan ini mengindikasikan bahwa pernikahan di Indonesia menjadi faktor penting yang mempengaruhi kepuasan hidup seseorang. Hasil studi ini senada dengan studi sebelumnya (Himawan 2019a), bahwa lajang cenderung dianggap sebagai periode sementara sebelum menikah.

Akan tetapi, ada dua hal yang perlu dipertimbangkan dalam menarik kesimpulan ini. Pertama, studi ini tidak mengontrol kualitas relasi pernikahan dan kualitas hidup lajang, sehingga ada kemungkinan partisipan yang berpartisipasi ialah hanya pasangan menikah yang puas dengan pernikahannya atau individu yang tidak puas dengan status lajangnya. Kedua, desain studi cross-sectional tidak dapat menyimpulkan relasi sebab akibat, bahwa menikah menyebabkan peningkatan kepuasan hidup. Namun, fakta bahwa mayoritas partisipan lajang tidak secara sukarela ingin melajang (involuntary single) dapat menjelaskan mengapa tingkat kepuasan hidupnya lebih rendah daripada partisipan menikah. Profil partisipan demikian juga memberi konteks penting bagi studi ini, yakni mengenai pentingnya mendiskusikan strategi coping yang efektif dalam menghadapi tan- 
tangan psikologis dan tekanan sosial akibat menyandang status lajang yang tidak diinginkan.

Pola-pola yang muncul dalam fase ini menjadi dasar penting dalam menyusun studi fase 2 . Secara khusus, investigasi lanjutan perlu difokuskan untuk mengetahui: 1). Bagaimana agama berperan dalam mengkonstruksi makna lajang, khususnya ketika status lajangnya tidak diinginkan?, 2). Apa wujud konkret aktivitas religios yang dilakukan lajang untuk mengatasi tantangan psikologis akibat status lajangnya? Kedua pertanyaan ini menjadi pedoman dalam menyusun kerangka studi fase 2 .

\section{FASE 1: METODE WAWANGARA}

\section{Partisipan}

Partisipan ialah 40 individu belum menikah dan tidak sedang berpacaran $($ Musia $=33.14 ; S D=$ 4.04), yang dipilih dengan kriteria yang sama dengan kriteria pada Fase 1. Sebelas partisipan dalam studi ini merupakan partisipan pada Studi Fase 1. Mayoritas partisipan ialah perempuan $(85 \%)$, beragama Islam (40\%), dan beretnis Jawa (50\%). Sementara itu komposisi agama lainnya ialah: Protestan (35\%), Katolik (20\%), dan Budha (5\%); sedangkan komposisi etnis lainnya mencakup: Tionghoa (25\%), Batak (10\%), Indonesia Timur (10\%), dan Sunda (5\%).

\section{Prosedur}

Wawancara dilakukan dalam bentuk tatap muka atau melalui platform Zoom, bergantung pada preferensi partisipan serta jarak geografis partisipan dengan peneliti. Undangan berpartisipasi studi disebar melalui cara yang sama dengan pada Fase 1. Partisipan diminta untuk mempelajari ketentuan studi, yang di dalamnya turut diinformasikan mengenai haknya untuk mengakhiri studi kapan pun ia merasa tidak nyaman. Partisipan menandatangani lembar persetujuan berpartisipasi sebelum diwawancarai. Setelah wawancara, apresiasi diberikan berupa voucher belanja senilai $\mathrm{Rp} 100.000,-$.

Pertanyaan wawancara disiapkan untuk mengeksplorasi area yang sesuai dengan pertanyaan penelitian dengan mempertimbangkan temuan pada fase 1, yang mencakup kehidupan spiritual partisipan (seberapa dalam partisipan menghayati nilai-nilai agamanya) serta bagaimana nilai-nilai agamanya mempengaruhi penilaian hidupnya, khususnya terkait dengan masa lajangnya. Wawancara berlangsung selama sekitar satu jam dan direkam dalam bentuk audio. Rekaman suara ini kemudian dikirim kepada transcriber independen untuk dikonversi menjadi verbatim.

\section{Teknik Analisis}

Verbatim hasil wawancara dianalisa melalui software NVivo dengan pendekatan analisis tematik yang mencakup tiga fase pengkodean (King and Horrocks 2010). Fase pertama ialah fase deskriptif, dimana respons-respons serupa dikategorikan dalam satu kelompok berdasarkan kesamaan semantik. Selanjutnya, kategori yang serupa diintegrasikan dalam fase pengkodean kategori sehingga didapat subtema-subtema yang representatif. Terakhir, melalui fase pengkodean analitik, subtema-subtema yang ada disusun dan disinergikan dengan pertanyaan penelitian. Tema-tema yang terbentuk kemudian didiskusikan dan disempurnakan bersama-sama antara peneliti dengan tiga orang tim peneliti yang memiliki keahlian di bidang kualitatif.

\section{HASIL DAN DISKUSI}

Studi fase ini mengeksplorasi bagaimana pemahaman terhadap nilai-nilai agama serta keterlibatan terhadap berbagai aktivitas keagamaan berperan dalam mengkonstruksi pengalaman melajang. Hasil wawancara mengilustrasikan tiga tema besar mengenai bagaimana pengalaman melajang yang dikonstruksikan oleh nilai-nilai agama: lajang sebagai masa pra-nikah yang dikehendaki Tuhan, sebagai masa untuk berkarya di luar lingkup rumah tangga, dan sebagai masa dimana nilai-nilai agama konservatif dikompromikan dengan perkembangan nilai budaya.

\section{Masa Pra-Nikah yang Dikehendaki Tuhan}

Mayoritas masyarakat Indonesia menghayati nilai-nilai agama dalam mengambil keputusan di dalam kesehariannya (Himawan 2012). Hal ini juga tercermin di dalam wawancara, dimana mayoritas 
partisipan $(n=36)$ mengaku bahwa aktivitas kesehariannya sangat diinspirasi oleh pemahaman agamanya. Mereka sepakat bahwa masa lajang merupakan masa yang diizinkan terjadi oleh Tuhannya demi kebaikannya. Tema ini dibagi menjadi tiga subtema: 1). lajang sebagai periode penantian menuju pernikahan, 2). lajang dan dosa akibat godaan seksual, dan 3). lajang sebagai masa untuk introspeksi dan meningkatkan kualitas diri serta pemahaman spiritual.

\subsection{Lajang sebagai Periode Penantian Menuju Per- nikahan}

Studi-studi yang pernah dilakukan tentang individu tidak menikah di Indonesia secara konsisten menunjukkan bahwa pernikahan masih menjadi sesuatu yang diharapkan, termasuk bagi generasi muda (Himawan 2019a, Situmorang 2007, Utomo 2003). Sikap serupa juga tercermin dalam studi ini. Serupa dengan temuan fase 1 , mayoritas partisipan $(n=38)$ menunjukkan sikap positif terhadap pernikahan dan menganggap masa lajangnya sebagai periode sementara yang akan berakhir dalam pernikahan.

Terpeliharanya sikap positif terhadap pernikahan yang melahirkan anggapan bahwa lajang merupakan periode sementara dipengaruhi oleh pemahaman agama partisipan. Sebagai contoh, Made (45 tahun, perempuan, Protestan), berkeyakinan bahwa menikah merupakan sesuatu yang dianjurkan kitab sucinya dengan mengutip ayat Alkitab (Pengkh. 4:9): "Berdua lebih baik daripada seorang dir". Namun ia pun mengakui bahwa Tuhan tidak memaksakan pengikut-Nya untuk menikah, sehingga menjadi lajang bukan serta-merta membuat seseorang berdosa.

Bagi partisipan beragama Islam, nuansa mengenai pentingnya menikah terlihat lebih kuat. Emma (32 tahun, perempuan, Islam) berpandangan bahwa menjadikan lajang sebagai pilihan hidup merupakan sesuatu yang dilarang oleh agamanya:

Jadi jika saya memang meniatkan diri untuk tidak menikah sama sekali seumur hidup itu nggak boleh [menurut ajaran agama yang saya pahami], tapi kalaupun ternyata selama niatan untuk menikah tapi memang jodohnya nggak ada ya itu, itu beda kasus.
Esti (29 tahun, perempuan, Islam) bahkan menyinggung rentang usia ketika seseorang dianjurkan menikah menurut ajaran agamanya:

"Dalam Islam itu sebenarnya anjurannya adalah kalau misalnya sudah akil baligh terus merasa sudah apa ya, cukup mapan ini ya, nggak mapan banget sih, tapi dianjurkan untuk segera menikah.

Pada partisipan yang beragama Buddha, menikah tetap dianggap dianjurkan oleh agamanya karena hidup selibat hanya ditujukan pada orangorang yang memang secara spesifik mendapat panggilan untuk tidak menikah, bukan pada mereka yang tidak dapat menemukan pasangan menikah.

\subsection{Lajang dan Dosa Akibat Godaan Seksual}

Bagi beberapa pemeluk agama Islam, menikah dianggap wajib sebagai wujud ibadah, terutama untuk membebaskan diri dari dosa akibat aktivitas seksual di luar nikah. Ita (30, perempuan) mendeskripsikan pandangannya tentang pernikahan dan zina serta cara yang harus dilakukan selama menanti pernikahan:

Yang pasti [menikah] harus disegerakan kalau sudah siap, harus disegerakan karena takutnya adalah zina, iya kan. Selama masih bisa menahan, kalau merasa belum siap [menikah], entah dalam hal ekonomi atau dalam pola pikir iya kan, itu bisa ditalangi dengan puasa dan sholat. Jadi kalau misalnya kamu sudah siap secara lahir dan batin, jangan pernah ditunda karena itu adalah hal yang baik.

Menghindari diri dari dosa zina tampak menjadi salah satu motivasi utama bagi beberapa pemeluk agama Islam untuk menikah. Hull (2016) menyebut pemahaman ini terinternalisasi dalam sistem nilai masyarakat Indonesia sehingga memelihara angka pernikahan dini terlepas dari semakin meningkatnya proporsi lajang.

Pemahaman ini juga menginspirasi sebuah gerakan sosial yang terjadi akhir-akhir ini: Gerakan Menikah Tanpa Pacaran, sebagaimana diceritakan oleh beberapa partisipan. Gerakan ini mempromosikan individu di usia menikah agar segera menikah tanpa melalui masa berpacaran atau dengan melalui tradisi Ta'aruf. Ini karena masa pacaran dianggap sebagai periode rentan bagi individu untuk 
terjerumus ke dalam dosa zina. Sebagai alternatifnya, ditawarkan tradisi pernikahan ta'aruf, dimana individu yang ingin menikah mengirimkan profil dirinya kepada murabbī atau murabbiya untuk diajukan ke Lajnah Munakahat, yang berperan menjodohkan berdasarkan profil kandidat yang diterimanya (Asyari and Abid 2016).

Pandangan tentang kerentanan lajang untuk berzina juga dibagikan oleh Redi (31 tahun, laki-laki) yang beragama Protestan. Namun ia mengaku komunitas agamanya sangat membantunya untuk tidak terjatuh dalam dosa akibat melakukan aktivitas seksual:

Jadi cari-cari kegiatan begitu, tapi yang gue telpon biasanya bukan teman yang sepadan dalam arti temanteman yang sudah kerja. Biasanya yang gue telpon itu anak-anak di gereja, yang mungkin masih kuliah be gitu ya yang cowok-cowok gue ajak beberapa orang begitu kayak, Ayok mau makan nggak, gue bayarin saja' gitu, ya lebih ke arah kayak gitu sih.

1.3 Lajang sebagai Masa untuk Introspeksi dan Meningkatkan Kualitas Diri serta Pemahaman Spiritual

Dalam menanti pernikahan, beberapa partisipan mengaku masa lajang merupakan masa yang diizinkan terjadi untuk mengintrospeksi diri dalam menghayati nilai-nilai agamanya. Hal ini diutarakan Angel (30 tahun, perempuan, Budha):

Kalau aku misalkan dapat rezeki, atau musibah aku selalu-, kan di agamaku kan percaya Karma ya, jadi perbuatan baik yang pernah aku buat itu mungkin berbuah, sehingga aku mendapatkan rezeki atau misalkan ketika aku ada musibah, oh mungkin ini karma masa lampau nih yang berbuah, sehingga sekarang aku dapat musibah:

Masa lajang juga dianggap penting untuk meningkatkan kualitas diri agar lebih mampu bersabar, bertekun, dan bersyukur di dalam situasi yang tidak diinginkan, sebagaimana diungkapkan Emma dan Dian sebagai berikut.

Saya Muslim begitu, jadi yang mendasar buat seorang Muslim salah satunya adalah bagaimana dalam keseharian kita bersyukur dan bersabar dengan apa yang kita punya. Kalau dengan apa yang sudah kita punya tentunya, apa namanya, attitude-nya adalah dengan ber- syukur, dan apa yang belum kita punya attitude-nya adalah dengan bersabar, bersabar dalam arti bersabar entah itu-, eh maksudnya bersabarnya karena ya mungkin memang itu belum jatah kita, atau mungkin nanti akan ada tapi ada masanya, atau ya mungkin memang itu ujian kamu di situ begitu.

(Emma; 32 tahun, perempuan, Islam)

Jadi, selalu mengingatkan diri bahwa ini [masa la jang] adalah waktu dan kehendak yang di atas. Saya juga sering mengingatkan diri untuk bersyukur tentang status saya, karena saya merasa kalau saya nggak bersyukur artinya saya tidak setuju dengan apa yang Tuhan rencanakan buat saya.

(Dian; 37 tahun, perempuan, Protestan)

Selain meningkatkan kualitas diri, memperdalam pemahaman spiritual juga menjadi cara beberapa partisipan dalam memaknai masa lajangnya, sebagaimana diungkap Norma (32 tahun, perempuan, Islam):

Untuk sekarang ini karena saya lebih banyak melakukan sesuatu yang lebih ke ibadah, jadi contohnya adalah setiap, hampir setiap hari itu adalah saya mendengarkan kajian dari ya guru agama begitu, ustadz-ustadz begitu melalui YouTube. Jadi, saya itu lebih, dulu, dulu itu saya sering merasakan kecemasan, nah karena saya sekarang lebih banyak beribadah jadi saya nggak merasakan kecemasan yang berlebihan.

Respons-respons di atas mendemonstrasikan bagaimana relasi spiritual dapat memfasilitasi kebutuhan seseorang untuk lekat (attachment need) pada figur di luar dirinya, yang penting bagi kesejahteraan psikologisnya (Kirkpatrick 1992). Secara khusus, temuan ini memberi dukungan empiris mengenai fungsi adaptif agama untuk meningkatkan kualitas hidup lajang (Granqvist and Hagekull 2009, Himawan, Bambling and Edirippulige 2018b), melalui terpenuhinya relasi spiritual dan sosial dalam lingkup keagamaan.

\section{Masa untuk Berkarya di Luar Lingkup Rumah Tangga}

Lajang juga dipahami sebagai masa dimana partisipan berkesempatan untuk berkarya melalui berbagai perannya di luar pernikahan. Penghayatan spiritual Flora (32 tahun, perempuan, Protestan) terhadap masa lajangnya membuatnya berkesimpulan 
bahwa masa lajang memberikan anugerah tersendiri baginya:

...buat saya juga anugerah juga sih Mas karena-, saya melihat tetap ada hal-hal yang memang khusus yang bisa saya lakukan di masa-masa ini begitu. Contohnya ini taking care of orang tua sendiri yang juga sudah masa lansia. Saya juga nggak tahu juga apa yang terjadi kalau seandainya semuanya ini terjadi dalam konteks saya sudah terikat dalam institusi pernikahan. Nggak mungkin saya punya fleksibilitas yang seperti sekarang begitu.

Dinamika spiritual yang dialami Victor (34 tahun, perempuan, Katolik) juga mengilustrasikan bagaimana ia menganggap bahwa melalui masa lajangnya, ia dapat menunjukkan produktivitas yang tinggi. Saat diwawancarai, Victor bekerja dalam bidang desain interior pada sebuah kontraktor swasta dengan posisi karier yang tinggi (top management). Ia merefleksikan bahwa seandainya ia berkeluarga, mungkin ia tidak dapat mencapai jenjang karier yang saat ini ia capai:

Kalau melihat ke belakang begitu nggak ada begitu yang bisa [jadi alasan untuk dihukum]. Jadi justru kalau saya nikah, mungkin itu hukuman buat saya. Menurut saya nggak [begitu] sih, bukan hukuman Tuhan tapi, saya lebih ke-, kontemplasinya adalah kenapa saya belum dikasih pasangan, terus saya lihat lagi supaya saya bisa berkarya karena kalau saya punya pasangan saya jadi nggak bisa berkarya [seperti sekarang].

Respons di atas mengilustrasikan bagaimana pemahaman spiritual dapat menciptakan perspektif alternatif bagi individu dalam memandang peristiwa yang terjadi di dalam hidupnya (Pargament and Park 1995). Dalam mengkonstruksi makna lajang, pemahaman spiritual partisipan memungkinkannya untuk melihat lajang sebagai masa yang diizinkan terjadi untuk sesuatu yang positif, bukan sebagai masa yang dilalui dengan penyesalan.

\section{Negosiasi Nilai-Nilai Agama Konservatif dengan Perkembangan Nilai Budaya}

Sebagian kecil partisipan $(\mathrm{n}=4)$ memposisikan agama sebagai satu dari beberapa identitas sosialnya; mereka tidak terlalu dipengaruhi penghayatan nilai agama dalam beraktivitas sehari-hari.
Ajaran agama dianggap penting untuk memelihara moral dan stabilitas sosial, begitu pula penyesuaian ajaran agama mereka anggap perlu agar dapat mengikuti dinamika nilai budaya. Seorang partisipan menyimpulkan pandangan tersebut sebagai "humanis", dimana esensi agama yang terpenting adalah menghormati hak-hak hidup orang lain.

Kalau saya lebih ke ini sih, lebih ke humanis sih, bukan ke arah agamis. Yang saya percaya ya, berbuat baik terhadap sesama, itu saja, jangan rugikan sesama, sudah.

(Soni, 32 tahun, lelaki, Katolik)

Ketika agama direduksi sebagai konstruksi sosial, makna-makna spiritual yang menyertainya diabaikan, termasuk dalam memaknai masa lajang. Partisipan dengan pandangan agama demikian cenderung merasa memiliki kontrol penuh atas tindakan serta peristiwa yang dialaminya, termasuk mengenai hal-hal apa yang boleh atau tidak boleh dilakukan. Pandangan Zety (29 tahun, perempuan, Protestan) memberi ilustrasi yang menarik untuk tema ini. Zety memiliki latar belakang budaya Jawa. Saat diwawancarai, ia sedang menempuh studi S3 di bidang kedokteran di luar negeri. Dalam kaitannya dengan penghayatan nilai-nilai agama, Zety percaya bahwa nilai-nilai agama perlu disesuaikan dengan konteks budaya.

Aku Kristen ya.. tapi dulu, em, kalau aku bilangnya Yesus, dia juga minum anggur kok. Dia juga mabok. Hehe. Jadi aku merasa gini..kalau ditanya seberapa besar agama mempengaruhi keputusan mungkin [agama] perlu menyesuaikan dengan hal-hal yang diterima secara kultur. Kayak merokok kalau di Indonesia, walau banyak orang bilang merokok itu haram, tapi banyak orang -, bahkan pemuka agama pun, merokok.

Dalam kaitannya dengan memenuhi kebutuhan seksual, Zety mengaku memiliki kehidupan seksual yang aktif dan tidak merasa berdosa karenanya. Baginya yang terpenting ialah lawan seksualnya juga menyetujuinya.

Saya bisa dibilang engaged in sexual activity [terlibat dalam aktivitas seksual], jai aku tidak, tidak apa ya, dalam itu aku sudah lebih kayak bule [orang asing], tetapi aku mempraktikkan safe sex [hubungan seks yang tidak berisiko]. Karena aku dokter, aku tahu, 


\section{aku cek HIV rutin.}

Bagi partisipan dalam kelompok ini, lajang dimaknai secara deskriptif sebagai suatu periode waktu dimana seseorang belum menikah. Mereka mengaku tidak mendapat tekanan untuk menikah, meski mereka tetap mengungkapkan keinginannya untuk menikah.

\section{KESIMPULAN}

Studi ini mengilustrasikan bagaimana agama memegang peran substansial dalam memberi perspektif untuk memaknai masa lajang dan memelihara kualitas hidup lajang. Hasil studi ini mengkonfirmasi peran adaptif maupun maladaptif agama dalam menjalani masa lajang melalui data empiris. Survei yang telah dilakukan menunjukkan bagaimana keterlibatan terhadap aktivitas keagamaan dapat mempromosikan kepuasan hidup lajang. Melalui wawancara, agama diketahui dapat menyajikan perspektif alternatif dalam memaknai lajang secara positif dan menawarkan cara mengatasi tantangan terkait status lajang melalui partisipasi terhadap berbagai komunitas dan ritual keagamaan.

Meskipun data studi ini tidak cukup untuk secara langsung menunjukkan bagaimana agama dapat menjadi sumber maladaptif dalam menjalani masa lajang, beberapa pola temuan dalam studi ini dapat mengilustrasikan risiko dimana agama dapat berdampak kontraproduktif bagi lajang. Secara umum, hasil studi ini menunjukkan bahwa peran agama terpolarisasi dalam dua bentuk: aturan (rules) dan relasi. Ketika penghayatan agama difokuskan pada aturan (dogma, ajaran, dan sederet aturan yang kaku), tanpa adanya relasi (spiritual dengan Tuhan), agama dapat menjadi sumber tekanan bagi lajang. Ini karena ajaran-ajaran agama, terutama tentang pentingnya menikah dan dosa berzina, dipahami secara kaku sebagai aturan yang membatasi. Jadi, peran adaptif agama hanya dapat dirasakan ketika seseorang mengimplementasikan ajaran agamanya secara berimbang.

\section{KETERBATASAN STUDI}

Temuan-temuan di dalam studi ini perlu di interpretasikan dengan mempertimbangkan keterbatasan yang menyertainya. Proporsi sampel yang kurang berimbang - didominasi oleh perempuan, dengan afiliasi agama Islam, dan berpendidikan universitas - mengimplikasikan bahwa temuan studi ini lebih relevan untuk merepresentasikan segmen masyarakat tertentu. Penggunaan online snowball sampling juga berpotensi menimbulkan bias seleksi partisipan, dimana beberapa partisipan yang memenuhi kriteria tidak dapat berpartisipasi karena tidak memiliki akses internet. Secara khusus, diskusi dalam studi ini juga perlu dipahami dalam konteks lajang yang bukan menjadi pilihan sukarela individu. Terakhir, desain studi non-longitudinal membuat relasi kausal tidak dapat dengan yakin disimpulkan.

\section{IMPLIKASI}

Peran agama dalam mengkonstruksi makna lajang pada studi ini menitikberatkan pada argumen teologis mengenai konsekuensi dosa akibat aktivitas seksual di luar nikah. Padahal, interpretasi teologis mengenai pernikahan lebih daripada sekadar aturan atau larangan mengekspresikan kebutuhan seksual. Oleh karena itu, penelitian lanjutan dapat menggali peran agama dalam mengkonstruksi makna lajang pada aspek lain, seperti persepsi peran dan kesetaraan gender di dalam keluarga. Studi berikutnya juga dapat berfokus pada satu agama spesifik sehingga analisis dapat dilakukan dengan lebih mendalam.

Dalam konteks praktis, hasil studi ini menunjukkan bahwa membangun pemahaman agama yang berimbang sangat penting dalam mendampingi lajang di Indonesia, khususnya bagi mereka yang beragama dan tidak secara sukarela menjadi lajang. Hal ini dapat dilakukan dengan tidak hanya menitikberatkan pada perintah dan larangan (rules) agama, tetapi juga memaknai dan menghayati relasi personal dengan Tuhan (atau figur spiritual yang dipercayainya). Dengan penghayatan yang seimbang, lajang dapat memaknai masa lajang sebagai masa yang dikehendaki-Nya untuk maksud baik, meski tidak dikehendakinya. 


\section{DAFTAR PUSTAKA}

Adamczyk, K. 2017. "Voluntary and Involuntary Singlehood and Young Adults' Mental Health: An Investigation of Mediating Role of Romantic Loneliness." Curr Psychol 36(4):888 904. doi: 10.1007/s12144-016-9478-3.

Asyari, Suaidi and M. Husnul Abid. 2016. "Expanding the Indonesian Tarbiyah Movement through TaAAruf and Marriage." Al-Jamiah: Journal of Islamic Studies 54(2):337-68. doi: 10.14421/ajis.2016.542.337-368.

Australian Bureau of Statistics. 2016. "Marriages and Divorces, Australia. 2015." Vol.

Badan Pusat Statistik. 2010. Indonesia Jumlah Dan Distribusi Penduduk. Jakarta: BPS

Baumeister, Roy F. and Mark R. Leary. 1995. "The Need to Belong: Desire for Interpersonal Attachments as a Fundamental Human Motivation." Psychological Bulletin 117(3):497-529. doi: 10.1037/0033-2909.117.3.497.

Beta, Annisa. R, dan Ryan Febrianto. 2020. "Are Indonesian Girls Okay? An Examination Of The Discourse Of Child Marriage, Victimization, And Humanitarian Visuality Of Global SouthGirls". Jurnal Studi Pemuda, Vol 9 (2). doi: 10.22146/studipemudaugm.57432

Cappellen, Patty Van, Maria Toth-Gauthier, Vassilis Saroglou and Barbara L. Fredrickson. 2016. "Religion and Well-Being: The Mediating Role of Positive Emotions." Journal of Happiness Study 17:485-505.

Chapman, Bruce and Cahit Guven. 2016. "Revisiting the Relationship between Marriage and Wellbeing: Does Marriage Quality Matter?". Journal of Happiness Study 17:533-51.

Colquhoun, Lisa., and Pamela Nilan. 2020. "Early Marriage among Sasak Boys in Rural North Lombok". Jurnal Studi Pemuda, Vol 9 (2). doi: 10.22146/studipemudaugm.56370

Corselli-Nordblad, Louise and Andrea Gereoffy. 2015. "Marriage and Birth Statistics-Living Together in the Eu." Vol.: Eurostat.

Creswell, John C. 2003. Research Design: Qualitative, Quantitative, and Mixed Methods Approaches. Thousand Oaks, CA: Sage.
Daugherty, Jull and Casey Copen. 2016. "Trends in Attitudes About Marriage and Sexual Behavior: United States, 2002, 2006-2010, and 2011-2013." Vol. 92. Centers for Disease Control and Prevention National Center for Health Statistic.

Depaulo, Bella M. 2009. "Men and Women Who Have Always Been Single Are Doing Fine." in Psychology Today.

DePaulo, Bella M. 2013. "Single in a Society Preoccupied with Couples." Pp. 302-16 in The Handbook of Solitude: Psychological Perspectives on Social Isolation, Social Withdrawal, and Being Alone, edited by R. J. Coplan and J. C. Bowker. Hoboken, NJ: John Wiley \& Sons.

Diener, E., R. A. Emmons, R. J. Larsen and S. Griffin. 1985. "The Satisfaction with Life Scale." J Pers Assess 49(1):71-5. doi: 10.1207/ s15327752jpa4901_13.

Dingemans, Ellen and Erik Van Ingen. 2015. "Does Religion Breed Trust? A Cross-National Study of the Effects of Religious Involvement, Religious Faith, and Religious Context on Social Trust." Journal for the Scientific Study of Religion 54(4):739-55.

Granqvist, Pehr and Berit Hagekull. 2009. "Religiosity, Adult Attachment, and Why "Singles" Are More Religious." The International Journal for the Psychology of Religion 10(2):111-23.

Hays, R. D. and M. R. DiMatteo. 1987. "A Short-Form Measure of Loneliness." J Pers Assess 51(1):69-81. doi: 10.1207/ s15327752jpa5101_6.

Himawan, Karel Karsten. 2012. Pemikiran Magis: Ketika Batas Antara Magis Dan Logis Menjadi Bias. Jakarta: Indeks.

Himawan, Karel Karsten, Matthew Bambling and Sisira Edirippulige. 2018a. "The Asian Single Profiles: Discovering Many Faces of Never Married Adults in Asia." Journal of Family Issues 39(14):3667-89. doi: $10.1177 / 0192513 \times 18789205$. 
Himawan, Karel Karsten, Matthew Bambling and Sisira Edirippulige. 2018b. "Singleness, Religiosity, and the Implications for Counselors: The Indonesian Case." Europe's Journal of Psychology 14(2):485-97. doi: 10.5964/ejop. v14i2.1530.

Himawan, Karel Karsten. 2019a. "Either I Do or I Must: An Exploration of the Marriage Attitudes of Indonesian Singles." The Social Science Journal 56(2):220-27. doi: 10.1016/j. soscij.2018.07.007.

Himawan, Karel Karsten. 2019b. "Motivations and Reactions to Social Undervaluation of Singles in the Married Society." Manuscript prepared for publication.

Himawan, Karel Karsten, Matthew Bambling and Sisira Edirippulige. 2019. "Modernization and Singlehood in Indonesia: Psychological and Social Impacts." Kasetsart Journal of Social Sciences 40:499-506. doi: 10.1016/j. kjss.2017.09.008.

Himawan, Karel Karsten. 2020a. "The Single's Struggle: Discovering the Experience of Involuntary Singleness through Gender and Religious Perspectives in Indonesia." The Family Journal in press. doi: 10.1177/1066480720950419

Himawan, Karel Karsten. 2020b. "Singleness, Sex, and Spirituality: How Religion Affects the Experience of Being Single in Indonesia." Mental Health, Religion \& Culture 23(2): 204-215. doi: 10.1080/13674676.2020.1767555.

Hirschl, T. A., J. Altobelli and M. R. Rank. 2003. "Does Marriage Increase the Odds of Affluence? Exploring the Life Course Probabilities." Journal of Marriage and Family 65:92738.

Hofstede Insights. 2018. "Country Comparison: Indonesia." Retrieved. (https://www.hofstede-insights.com/country-comparison/indonesia/).

Hull, Terence H. 2016. "Indonesia's Fertility Levels, Trends and Determinants: Dilemmas of Analysis." Pp. 133-51 in Contemporary Demographic Transformations in China, India and Indonesia, edited by C. Z. Guilmoto and G. W. Jones. Switzerland: Springer Cham.
Ibrahim, Rozita and Zaharah Hassan. 2009. "Understanding Singlehood from the Experiences of Never-Married Malay Muslim Women in Malaysia: Some Preliminary Findings." European Journal of Social Sciences 8(3):395405.

Jones, Gavin W. 2010. Changing Marriage Patterns in Asia. Singapore: Asia Research Institute.

Jones, Gavin W., Zhang Yanxia and Pamela Chia Pei Zhi. 2012. "Understanding High Levels of Singlehood in Singapore." Journal of Comparative Family Studies 43(5):731-50.

King, Nigel and Christine Horrocks. 2010. Interviews in Qualitative Research. Thousand Oaks, CA: Sage.

Kirkpatrick, Lee A. 1992. "An Attachment-Theory Approach Psychology of Religion." The International Journal for the Psychology of Religion 2(1):3-28.

Lucas, R. E., A. E. Clark, Y. Georgellis and E. Diener. 2003. "Reexamining Adaptation and the Set Point Model of Happiness: Reactions to Changes in Marital Status." J Pers Soc Psychol 84(3):527-39. doi: 10.1037//00223514.84.3.527.

McConnell, Kelly M., Kenneth I. Pargament, Christopher G. Ellison and Kevin J. Flanelly. 2006. "Examining the Links between Spiritual Struggles and Symptoms of Psychopathology in a National Sample." Journal of Clinical Psychology 62(12):1469-84.

Myers, D. G. 2000. "The Funds, Friends, and Faith of Happy People." Am Psychol 55(1):5667. doi: 10.1037//0003-066x.55.1.56.

Pargament, Kenneth I., Hannah Olsen, Barbara Reilly, Kathryn Falgout, David S. Ensing and Kimberly Van Haitsma. 1992. "God Help Me (Ii): The Relationship of Religious Orientations to Religious Coping with Negative Life Events." Journal for the Scientific Study of Religion 31(4):504-13.

Pargament, Kenneth I. and Crystal L. Park. 1995. "Merely a Defense? The Variety of Religious Means and Ends." Journal of Social Issues 51(2):13-32. 
Sarkisian, Natalia and Naomi Gerstel. 2016. "Does Singlehood Isolate or Integrate? Examining the Link between Marital Status and Ties to Kin, Friends, and Neighbors." Journal of Social and Personal Relationships 33(3):361-84.

Saroglou, Vassilis. 2009. "The Four Basic Dimensions of Religiousness Scale." edited by C. U. o. Louvain. Catholic University of Louvain, Belgium.

Setyonaluri, Diahhadi., Aidah Maghfirah., dan Calvin Aryaputra. 2020. "Norms in transition? The Relationship between Education and Singlehood". Jurnal Studi Pemuda, Vol 9 (2). doi:10.22146/studipemudaugm.57995

Situmorang, Augustina. 2007. "Staying Single in a Married World." Asian Population Studies 3(3):287-304.

Tan, Joo Ean. 2010. "Social Relationships in the Modern Age: Never-Married Women in Bangkok, Jakarta, and Manila." Journal of Comparative Family Studies 41(5):749-65.

United Nations. 1948. "Universal Declaration of Human Rights." Retrieved. (https://www.un.org/en/universal-declaration-human-rights/).

US Census Bureau. 2015. "Figure Ms-2. Median Age at First Marriage: 1890 to Present." Vol.
Utomo, Ariane J. 2014. "Marrying Up? Trends in Age and Education Gaps among Married Couples in Indonesia." Journal of Family Issues 35(12):1683-706. doi: $10.1177 / 0192513 \times 14538023$.

Utomo, Iwu. 2003. "Can Being Single Become a Choice for Young Indonesians? Generational Differences." Developmental Bulletin 62:97103.

Vignato, Silvia. 2012. "Men Come in, Men Go Out': Single Muslim Women in Malaysia and Aceh." Social Identities: Journal for the study of race, nation and culture 18(2):23957. doi: 10.1080/13504630.2012.652847.

Yeung, Wei-Jun Jean and Shu Hu. 2016. "Paradox in Marriage Values and Behavior in Contemporary China." Chinese Journal of Sociology 2(3):447-76. doi: $10.1177 / 2057150 \times 16659019$. 